\title{
VALIDITAS NEW INJURY SEVERITY SCORE (NISS) DALAM MENDETEKSI TERJADINYA KOAGULOPATI PADA PASIEN MULTIPLE TRAUMA
}

\author{
I Komang Yose Antara ${ }^{1}$, I Ketut Wiargitha ${ }^{2}$, Tjokorda G.B. Mahadewa ${ }^{3}$ \\ ${ }^{1}$ Program Pendidikan Dokter Spesialis Bedah, Fakultas Kedokteran Universitas Udayana, Denpasar, Indonesia. \\ Korespondensi: yose_ant@yahoo.com \\ ${ }^{2}$ Subbagian Bedah Trauma dan Bedah Akut, Bagian Ilmu Bedah Fakultas Kedokteran Universitas \\ Udayana/Rumah Sakit Umum Pusat Sanglah, Denpasar, Indonesia. \\ ${ }^{3}$ Subbagian Bedah Saraf, Bagian Ilmu Bedah Fakultas Kedokteran Universitas Udayana/Rumah Sakit Umum \\ Pusat Sanglah, Denpasar, Indonesia.
}

\begin{abstract}
ABSTRAK
Tujuan: untuk mencari validitas new injury severity score (NISS) dalam mendeteksi koagulopati akut pada pasien multiple trauma. Metode: penelitian ini adalah uji diagnostik dengan rancangan cross sectional, dilakukan untuk mencari validitas NISS dalam mendeteksi terjadinya koagulopati akut pada 61 pasien multiple trauma dengan ISS $>16$. Penelitian dilakukan di RSUP Sanglah Denpasar sejak bulan Januari 2014 hingga November 2015. Data dianalisis dengan menggunakan kurva ROC dan uji diagnostik tabel $2 \times 2$ sehingga didapatkan area under curve, cut off point, sensitifitas, spesifisitas, nilai prediksi positif, nilai prediksi negatif, rasio kemungkinan positif, dan rasio kemungkinan negatif. Hasil: didapatkan cut off point NISS 41 dengan AUC 0,8851 (>0,7). Sensitifitas dan spesifisitas NISS cukup baik dalam mendeteksi terjadinya koagulopati akut pada pasien multiple trauma yaitu sebesar 79,2\% dan 91,8\% (CI 95\%: 0,78-0,98). Hasil nilai prediksi positif $86,4 \%$, nilai prediksi negatif $87,2 \%$, rasio kemungkinan positif 9,76 dan rasio kemungkinan negatif 0,227 mendukung bahwa nilai diagnostik NISS cukup baik. Simpulan: validitas NISS cukup baik dalam mendeteksi terjadinya koagulopati akut pada pasien multiple trauma.
\end{abstract}

Kata kunci: multiple trauma, koagulopati akut, NISS, ROC, uji diagnostik.

\section{VALIDITY OF NEW INJURY SEVERITY SCORE (NISS) TO DETERMINE COAGULOPATHY IN MULTIPLE TRAUMA PATIENTS}

\author{
I Komang Yose Antara ${ }^{1}$, I Ketut Wiargitha ${ }^{2}$, Tjokorda G.B. Mahadewa ${ }^{3}$ \\ ${ }^{1}$ Genaral Surgery Training Programme, Faculty of Medicine, Udayana University, Sanglah General Hospital, \\ Denpasar, Indonesia. \\ ${ }^{2}$ Trauma and Acute Care Surgery Division, Surgery Department, Faculty of Medicine Udayana University, \\ Sanglah General Hospital, Denpasar, Indonesia. \\ ${ }^{3}$ Neurosurgery Division, Surgery Department, Faculty of Medicine Udayana University, Sanglah General \\ Hospital, Denpasar, Indonesia.
}

\begin{abstract}
Objective: to find validity of new injury severity score (NISS) in detecting acute coagulopathy in multiple trauma patients. Methods: this study is diagnostic test with cross sectional design to find validity of NISS to determine coagulopathy of 61 multiple trauma patients with ISS $>16$. The study was conducted in Sanglah Public Hospital since January 2014 until November 2015. The data were processed with ROC curve and diagnostic test $2 \times 2$ table with the result area under curve, cut off point, sensitifity, spesificity, positive predictive value, negative predictive value, positive likehood ratio, and negative likehood ratio. Results: cut off point NISS 41 with AUC 0.8851 (>0.7). NISS sensitifity
\end{abstract}


79.2\% and spesifisity $91.8 \%$ (CI 95\%: $0.78-0.98$ ) is good enough to determine acute coagulopathy in multiple trauma patients. Positive predictive value, negative predictive value, positive likelihood ratio, and negative likelihood ratio were $86.4 \%, 87.2 \%, 9.76,0.227$, respectively. This result showed that the diagnostic test of NISS is good enough. Conclusion: validity of NISS is good enough to determine acute coagulopathy in multiple trauma patients.

Keywords: multiple trauma, acute coagulopathy, NISS, ROC, diagnostic test.

\section{PENDAHULUAN}

Permasalahan pada multiple trauma yang sering dihadapai saat ini adalah trias kematian yaitu asidosis, hipotermia, dan koagulopati. ACoTS (acute coagulopaty of trauma shock) menyebabkan peningkatan mortalitas empat kali lebih besar dibandingkan bila koagulopati akut tidak terjadi. ${ }^{1-5}$ Multiple trauma merupakan pasien dengan injury severity score (ISS) lebih dari 16 poin. ISS dan new injury severity score (NISS) menunjukkan beratnya trauma berdasarkan anatomi dan secara tidak langsung menunjukkan besarnya kerusakan jaringan yang terjadi pada pasien. Kerusakan jaringan akan menyebabkan rangsangan pada proses koagulasi sehingga akan menyebabkan terjadinya koagulopati konsumtif. Sebuah penelitian menyebutkan bahwa pasien trauma dengan ISS sekitar 40 poin dan NISS sekitar 50 poin meninggal saat datang. ${ }^{6}$ Semakin besar ISS dan NISS semakin cepat pasien meninggal. Deteksi awal komplikasi yang terjadi pada trauma seperti ACoTS sangat penting untuk mencegah meningkatnya mortalitas. ${ }^{6}$

Penelitian menunjukkan bahwa NISS memiliki akurasi yang lebih tinggi daripada ISS dalam menilai beratnya trauma jaringan sebagai prediktor adanya kegagalan multi organ pada post trauma. Hal ini disebabkan karena perhitungan skor pada ISS berdasarkan tiga bagian tubuh yang mengalami trauma terberat.
Hal ini dapat menimbulkan underscoring jika pada satu bagian tubuh terdapat lebih dari satu organ yang mengalami trauma.,

Penelitian tentang validitas NISS untuk mendeteksi adanya koagulopati akut pada pasien trauma belum pernah dilakukan. Penelitian ini bertujuan untuk mencari validitas NISS dalam mendeteksi terjadinya koagulopati akut pada pasien multiple trauma.

\section{METODE}

Penelitian uji diagnostik dengan rancangan penelitian cross sectional dilakukan pada Januari 2014 hingga November 2015 dengan cara studi rekam medis dan pemeriksaan langsung pada pasien multiple trauma yang datang di instalasi gawat darurat RSUP Sanglah Denpasar. Subyek dipilih secara acak sistematis, dihitung dengan rumus perhitungan sampel menggunakan tabel perhitungan besar sampel untuk penelitian diagnostik dengan keluaran area under curve (AUC). Nilai AUC INR (international normalized ratio) pada penelitian sebelumnya sebesar $0,82,{ }^{9}$ sehingga diperlukan sebanyak 60 subyek.

Kriteria inklusi untuk penelitian ini adalah pasien yang berumur $\geq 16$ tahun dengan multiple trauma yang memiliki ISS $>16$ dan setuju untuk diikutkan dalam penelitian. Kriteria eksklusi adalah pasien menolak menjadi sampel penelitian. Pada sampel akan dilakukan penghitungan NISS 
dan pengambilan sampel darah sebanyak $5 \mathrm{ml}$ untuk pemeriksaan kadar INR yang merupakan baku emas dalam penelitian ini. INR positif koagulopati jika nilainya $\geq 1,2$. INR negatif koagulopati jika nilainya $<1,2$.

Data yang diperoleh disajikan dalam bentuk narasi dan tabel, dilakukan analisis dengan kurva ROC untuk menentukan cut of point dari NISS. Dari data yang terkumpul akan dihitung sensitivitas, spesifisitas, nilai prediksi positif (NPP), nilai prediksi negatif (NPN), rasio kemungkinan positif $(\mathrm{RK}+)$, rasio kemungkinan negative (RK-), serta posttest probabilitynya.

\section{HASIL}

Selama rentang waktu Januari 2014 sampai Nopember 2015 didapatkan 61 pasien multiple trauma yang memenuhi kriteria inklusi. Karakteristik sampel dapat dilihat pada tabel 1.

Tabel 1. Gambaran karakteristik dan variabel penelitian

\begin{tabular}{lc}
\hline Karakteristik & Sampel $(\mathbf{n}=\mathbf{6 1})$ \\
\hline $\begin{array}{l}\text { Umur (tahun) } \\
\text { Mean }\end{array}$ & $35+\mathrm{SD}$ \\
Jenis Kelamin & \\
Laki-laki & $41(67,2 \%)$ \\
$\quad$ Perempuan & $20(32,8 \%)$ \\
ISS & \\
Mean & $28 \mathrm{SD}$ \\
NISS & \\
Mean & $34+\mathrm{SD}$ \\
INR & \\
Mean & $1,14+\mathrm{SD}$ \\
Koagulopati & \\
Ya & $24(39,3 \%)$ \\
Tidak & $37(60,7 \%)$ \\
\hline
\end{tabular}

Pada analisis kurva ROC didapatkan area under ROC curve sebesar 0,8851 dengan nilai sensitifitas dan spesifisitas terbaik pada cut off point NISS 41. Dengan demikian nilai NISS $\geq 41$ dinyatakan koagulopati dan NISS $<41$ tidak koagulopati (gambar 1).

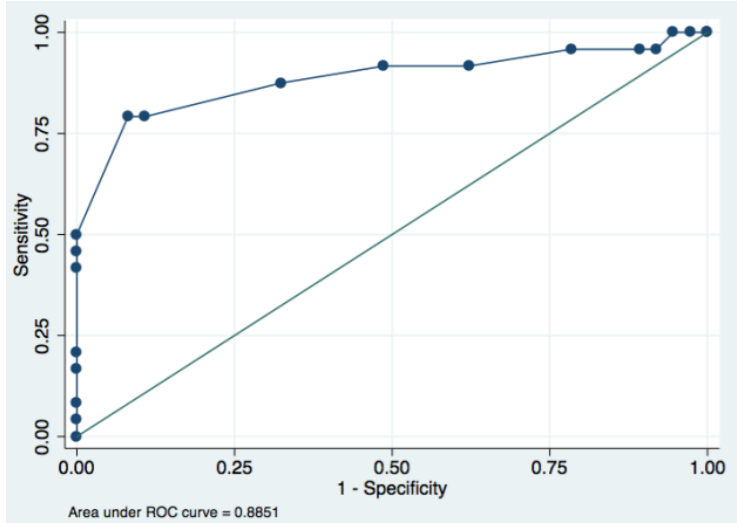

Gambar 1. Kurva ROC kemampuan NISS dalam mendeteksi terjadinya koagulopati akut pada pasien multiple trauma.

Dari 61 sampel, didapatkan 24 sampel yang mengalami koagulapati akut berdasarkan nilai INR dan 22 sampel berdasarkan NISS. Sebanyak 37 sampel yang tidak mengalami koagulopati akut berdasarkan nilai INR dan 39 berdasarkan NISS (tabel 2). Sensitifitas dan spesifisitas NISS dalam mendeteksi terjadinya ACoTS pada pasien multiple trauma sebesar $79,2 \%$ dan 91,8\% (CI 95\%) dengan NPP 86,4\% (65,1-97,1\%), NPN 87,2\% (72,6-95,7\%), RKP 9,76 (3,24-29,4), dan RKN 0,227 $(0,103-0,497)$.

Tabel 2. Hasil uji diagnostik NISS dalam mendeteksi terjadinya koagulopati pada pasien multiple trauma

\begin{tabular}{|c|c|c|c|}
\hline INR & \multicolumn{2}{|c|}{ Koagulopati } & \multirow[b]{2}{*}{ Total } \\
\hline NISS & $\begin{array}{c}\mathrm{Ya} \\
(\mathrm{INR} \\
\geq 1,2)\end{array}$ & $\begin{array}{l}\text { Tidak } \\
(\text { INR } \\
<1,2)\end{array}$ & \\
\hline \multicolumn{4}{|c|}{ Koagulopati } \\
\hline $\mathrm{Ya}(\geq 41)$ & 19 & 3 & 22 \\
\hline
\end{tabular}




\begin{tabular}{cccc} 
Tidak $(<41)$ & 5 & 34 & 39 \\
\hline Total & 24 & 37 & 61 \\
\hline
\end{tabular}

\section{DISKUSI}

Penelitian ini menemukan bahwa lakilaki lebih banyak mengalami multiple trauma dengan mean usia 35 tahun. Hal ini sesuai data dari WHO (World Health Organization) 2006 yang menyebutkan bahwa multiple trauma lebih banyak terjadi pada laki-laki yaitu $78,6 \%$ dengan mean umur pasien 32,5 tahun. Hal ini disebabkan karena mayoritas multiple trauma terjadi pada laki-laki usia muda yang disebabkan oleh kecelakaan lalu lintas. $^{10}$

Perbedaan nilai median ISS 27 dan NISS 34 pada penelitian ini disebabkan karena adanya underscoring pada ISS. Pada ISS hanya diperhitungkan AIS dari bagian tubuh tanpa memperhitungkan organ sedangkan NISS memperhitungkan AIS dari setiap organ yang mengalami trauma. ${ }^{7}$ Sistem skoring trauma dengan NISS memperkirakan besarnya kerusakan jaringan secara anatomi. Kerusakan jaringan pada trauma berhubungan erat dengan inflamasi, konsumsi faktor-faktor koagulasi, perdarahan, adanya syok, hemodilusi, hipotermia dan asidosis. Keseluruhan akibat dari kerusakan jaringan ini berakhir pada komplikasi koagulopati akut. ${ }^{11}$ Dengan demikian, semakin besar nilai NISS, semakin besar pula kemungkinan terjadinya koagulopati akut.

Penelitian retrospektif yang dilakukan. Maegele menyebutkan $34 \%$ pasien mengalami koagulopati akut saat datang akibat trauma tumpul. Hal ini menunjukkan bahwa satu dari tiga pasien trauma yang datang mengalami ACoTS. 1,3,4 Hasil yang tidak berbeda jauh didapatkan pada penelitian ini dimana didapatkan 39,3\% pasien multiple trauma mengalami koagulopati akut saat datang di instalasi gawat darurat. Mortalitas pada pasien multiple trauma dengan ACoTS pada penelitian ini sebesar $33,3 \%$ (8 pasien). Penelitian yang dilakukan Brohi pada tahun 2007 didapatkan sebesar sebesar 62\% sedangkan Maegele pada tahun 2007 sebesar 28\%. Perbedaan ini kemungkinan disebabkan karena jumlah sampel dan lokasi yang diteliti berbeda pada setiap penelitian. ${ }^{3,12}$

Pada analisis kurva ROC didapatkan cut off point terbaik pada nilai NISS 41. Nilai NISS $\geq 41$ memberikan nilai sensitifitas dan spesifisitas terbaik dalam mendeteksi terjadinya koagulopati akut pada pasien multiple trauma. Penelitian yang dilakukan Maegele pada tahun 2007 hanya menyebutkan mean ISS 24 dengan persentase ACoTS pada trauma sebesar 34\%. ${ }^{3,11}$ Penelitian ini lebih spesifik dan lebih baik karena memberikan hasil uji diagnostik NISS dalam mendeteksi terjadinya koagulopati akut pada pasien multiple trauma. Selain itu seperti yang disebutkan pada penelitian-penelitian sebelumnya bahwa NISS memiliki nilai prediksi yang lebih baik daripada ISS. ${ }^{7}$

Pemeriksaan baku emas untuk koagulopati akut pada pasien multiple trauma dilakukan dengan pemeriksaan laboratorium darah yaitu pemeriksaan INR. Pada kondisi trauma, setiap pemeriksaan laboratorium yang digunakan untuk mengidentifikasi adanya koagulopati akut membutuhkan waktu sedangkan ketika hasil laboratorium keluar, pasien mungkin sudah dalam keadaan ACoTS yang irreversibel. Penelitian ini dapat direkomendasikan sebagai alternatif dalam mendeteksi terjadinya koagulopati akut pada pasien multiple trauma. ${ }^{13}$ NISS 
sangat mudah dan dapat langsung dihitung ketika diagnosis sudah ditegakkan. Sensitifitas dan spesifisitas NISS dalam mendeteksi terjadinya koagulopati akut pada pasien multiple trauma sebesar 79,2\% dan $91,8 \%$ yang menunjukkan validitas NISS cukup baik dalam mendeteksi terjadinya koagulopati akut pada pasien multiple trauma.

\section{SIMPULAN}

Hasil uji diagnostik validitas NISS dalam mendeteksi terjadinya koagulopati akut pada pasien multiple trauma menunjukkan nilai validitas yang baik dengan cut off point NISS 41.

\section{DAFTAR PUSTAKA}

1. Anusha, C, Udupi B. Acute coagulopathy of trauma: Mechanism, monitoring, management. World Journal Anesthesiology. 2014;3:111-8.

2. Hess JR, Brohi K, Dutton RP, et al. The Coagulopathy of Trauma: A Review of Mechanisms. J Trauma. 2008;65:748-54.

3. Maegele $M$, Lefering $R$, Yucel $N$. Early coagulopathy in multiple injury: an analysis from the German Trauma Registry on 8724 patients. Injury. 2007;38:298-304.

4. Brohi K, Singh J, Heron M, Coats T. Acute traumatic coagulopathy. $J$ Trauma. 2003;54:1127-30.

5. MacLeod JB, Lynn M, McKenney, MG, et al. Early coagulopathy predicts mortality in trauma. $J$ Trauma. 2003;55:39-44.

6. Mica L, Rufibach K, Keel M, Trentz O. The Risk of Early Mortality of Polytrauma Patients Associated to ISS, NISS, APACHE II Values and Prothrombin. Journal of Trauma Management and Outcomes. 2013;7.
7. Chawda MN, Hildebrand F, Pape HC, Giannoudis PV. Predicting Outcome After Multiple Trauma: Which Scoring System?. The International Journal of The Care of The Injured. 2004;35:34758.

8. Balogh Z, Offner PJ, Moore EE, Biffl WL. NISS predicts post injury multiple organ failure better than the ISS. $J$ Trauma. 2000;48:624-7.

9. Hagemo JS, Christian SC, Stanworth SJ, et al. Detection of Acute Traumatic Coagulopathy and Massive Transfusion Requirements by Means of Rotational Thromboelastometry: an International Prospective Validation Study. Crit Care. 2015;19:97.

10. Fiona EL, Omar B, Woodford M, et al. Epidemiology of Polytrauma. In: Pape H-C, Peitzman AB, Schwab CW, et al, editors. Damage Control Management in the Polytrauma Patient. New York: Springer Science+Business Media. 2010.p.13-24.

11. Maegele M, Thomas P, Bertil B. Acute Traumatic Coagulopathy in Severe Injury: Incidence, Risk Stratification, and Treatment Options. Dtsch Arztebl Int. 2011;108:827-35.

12. Brohi K, Cohen MJ, Davenport RA. Acute Coagulopathy of Trauma: Mechanism, Identification and Effect. Curr Opin Crit Care. 2007;13:680-5.

13. Thorsen K, Ringdal KG, Strand K, et al. Clinical and cellular effects of hypothermia, acidosis and coagulopathy in major injury. $\mathrm{Br} J$ Surg. 2011;98:894-907. 